\title{
Ungdomsprotest - »Ny subjektivitet«, modstand eller integration?
}

\author{
Lars Bjфrnshauge
}

\section{Indledning.}

Hensigterne med det følgende er

- at diskutere 80'ernes ungdomsuroligheder i relation til ungdommen generelt i de højtudviklede kapitalistiske samfund. Ungdomsprotesten har kraftigt manifesteret sig i Vesttyskland, men snart sagt alle de vesteuropæiske lande har i større eller mindre grad oplevet de ny protestformer. Det meste af bidraget vil basere sig på den vesttyske diskussion, der er blevet ret omfattende.

- at belyse »ungdomsproblemernes« grundliggende samfundsmæssige karakter, det vil sige indskrive dem i en sammenhæng med kvalitative udviklinger i reproduktionsforholdene.

- at bidrage med teser til diskussionen af sammenhængen mellem unge, ungdomsprotest, ungdommens samfundsmæssige integration og samfundsforandrende bevægelser.

På trods af diskussionens »importerede « karakter, mener jeg, at den også har udsagnskraft - omend modificeret - i en dansk sammenhæng. Hvis det hele kan bidrage til, at ungdomsprotesten og dens samfundsmæssige og politiske »signalfunktion « vil blive taget alvorligt, vil meget være nået.

80'erne blev en brat opvågnen for regeringskommisærer, ungdomsforskere og journalister. I kølvandet på studenteroprøret var klicheer som »någeneration « blevet hverdagskost til beskrivelse af de sene 70'eres ungdom. Så »pludselig « ved indgangen til 80'erne brød helvede løs. Grupper af unge stod radikalt af samfundet. Husbesættelser, ta'-selv aktioner, kampe for frie, selvforvaltede ungdomscentre og i det hele taget unges uforholdsmæssigt store deltagelse ${ }^{1} \mathrm{i}$ alternative livsformer, bevægelser og nye sociale bevægelser var blevet unges måde at manifestere sig på. I det følgende vil disse fænomener blive betegnet ungdomsprotest, og skal som sådan forstås som et potentiale indenfor ungdommen. Ungdomsprotesten tematiserer grundliggende samfundsmæssige forandringer ${ }^{2}$. I forlængelse heraf bliver

1. Brand s. 157 , Eckert s. 143, Dörre \& Schäfer s. 141.

2. Dörre \& Schäfer s. 136. 
ungdomsprotesten et politisk, socialpsykologisk fænomen, hvor dele af ungdommen mere eller mindre organiseret, men trods alt i gruppesammenhæng offensivt, aggressivt, fantasifuldt og spontant ytrer deres utilfredshed med mangler, »ubehag « og »ikke-tilfredsstillelse « af menneskelige og samfundsmæssige behov og samtidigt forsøger at gøre noget ved det her og nu? ${ }^{3}$.

I det følgende forsøges dette protestpotentiale identificeret, dets samfundsmæssige baggrunde blotlagt og det forsøges indskrevet i en samfundsforandringssammenhæng, for sluttelig at antyde ungdommens integration som samfundsproblem.

\section{II »I gaderne stiger feberen « \\ - ungdomsprotestens praksis. ${ }^{4}$}

Som antydet er ungdomsprotesten først og fremmest et storbyfænomen. Mest kendt er begivenhederne omkring autonome ungdomscentre i Zürich og husbesættelser i Berlin og Amsterdam. At disse byer repræsenterer de mest spektakulære begivenheder bør ikke bortlede opmærksomheden fra, at der er tale om langt mere udbredte fænomener.

Udgangspunktet for de radikale ungdomsgruppers udfordring af »normalsamfundet « har været kampen for frie, selvforvaltede rum i storbyerne, altså umiddelbart en kamp om $\mathrm{m}^{2}$. Den autoritære omstrukturering og gennemfunktionalisering af storbyerne efterlader overalt huller - tomme huse, forladte fabriksbygninger og udtjente kontorhuse, som okkuperes og erklæres for befriede rum. Bag denne kamp om plads skjuler der sig et helt register af behov, ønsker, protest og kritik, og et helt program for eksperimenter med arbejds-, bo-og samværsformer og sociale relationer.

De radikale unges program og praksis lader sig begribe som sub-og modkulturel. ${ }^{5}$ Kraftigt inspireret af punk-kulturen udvikles specielle stiltræk og symbolikker. Klædningsmæssig, sproglig og musikalsk tilegnelse og omformning er karakteristisk.

I deres miljøer eksperimenteres der med samlivsformer kraftigt influeret af kollektiv- og kvindebevægelsens landvindinger. Kønsrollerne forsøges ombrudt, ligesom klare anti-elitære, anti-autoritære og anarkistiske værdier er fremherskende.

3. Bopp s. $177 \mathrm{ff}$.

4. Indenfor rammerne af dette bidrag er det overhovedet ikke muligt blot rimelig autentisk at gengive ungdomsprotestens praksis. Der henvises til: Aust \& Rosenbladt, Bacia \& Scherer, Brandes \& Schön, Breyvogel, Haller, Jensen, Madsen m.fl. Müller-Münch, for et kort rids se Bjørnshauge.

5. Nærmere om subkulturanalyse: Bay, Hebdige, Illeris m.fl. og Mørch. 
Basisdemokratiske beslutningsstrukturer forsøges afprøvet, hvilket kommer til udtryk også i de mere »organiserede« husbesættermiljøer i Berlin og Amsterdam. På trods af at der her er involveret flere tusinde unge er der udpræget autonomi for de enkelte enheder, og man vil lede forgæves efter ledere, talsmænd og "pinger «.

Centralt er behovet for selvbestemmelse defineret som modsætning til »voksensamfundets « gennemregulering og omklamring af de unge. Der er tale om en nærmest total afvisning af værdigrundlaget for den dominerende livsform. De afviser overvågning, hvadenten den har skikkelse af forældre, pædagoger, lærere, socialarbejdere eller politifolk, og insisterer på at »vi kan selv«.

Dette gælder i forhold til arbejde, politik og kultur. Kritikken af lønarbejdet er kontant. Fremfor at tilbringe livet ved et fremmedbestemt, monotont og psykisk ødelæggende lønarbejde prøver de at »arbejde« i deres erobrede rum, hvor de selv bestemmer hvor, hvornår, hvordan og til hvilket formål deres produktive og skabende aktivitet skal anvendes. De forsøger at indfri deres radikale krav til arbejdet, det skal være selvorganiseret, meningsfyldt samt personligt og socialt udviklende.

Ligeledes fors $\emptyset$ ger de at overvinde hverdagslivets opsplitning ved at integrere arbejde, fritid, politisk arbejde og udvikling af sociale relationer. Idealet er et hverdagsliv præget på en gang af selvbestemmelse, kollektivitet, solidaritet og befriet for konsumtvang og gennemrationalisering.

I deres aktioner og aktiviteter ligger også en radikal kritik af traditionel (venstrefløjs-) politisk praksis. Politik på den traditionelle måde har disse unge prøvet og der er ikke høstet brugbare erfaringer ad den vej. De udvikler deres egen politiske praksis, hvis første karakteristikum er action!. Med udgangspunkt i den opfattelse at politik er noget man skal kunne have sig selv med i, bliver politik og politisk aktion først og fremmest noget der skal være sjovt, noget med gang i, hvor fantasi, spontaneitet og uberegnelighed er væsentlige ressourcer. Det er den enkeltes deltagelse der er det centrale, ikke noget med at lade sig repræsentere, ingen forhandlere, ingen ledere.

Dette ultrakorte omrids af kritik- og protestpunkter og konkrete praksisser tegner billedet af et forsøg på at etablere en helt anderledes livsform, med et helt andet værdigrundlag end det dominerende i samfundet og den herskende kultur.

Dette lynhurtige rids er naturligvis for generelt og idealiserende. Et par forbehold bør imidlertid være tilstrækkeligt i denne sammenhæng. For det første bliver disse frirum hjemsøgt af ligepræcis sådanne samfundsmæssige, sociale og psykiske problemer som ikke får lov at blive bragt til 
udtryk på en relevant måde i »normalsamfundet « og dets institutioner. ${ }^{6}$ Og for det andet bidrager den generelle kriminalisering og daglige repres$\operatorname{sion}^{7}$, som disse frirum ofte er genstand for, til at de får karakter af »fæstninger « $\mathrm{i}$ mere end en forstand. Angst og paranoia kan her få rimelige funktionsbetingelser, ligesom militans bliver en dyd i sig selv, hvilket i mange tilfælde kan føre til afskalning af mere »bløde« grupper efterhånden som »fæstningskuller« og macho-prægede »streetfighter«-tendenser udbredes. ${ }^{8}$

Det ovenstående skulle antyde, at det vil være en kraftig forkortning at uddefinere ungdomsprotesten til at være udtryk for pubertetsproblemer og apolitiske ungdomsgriller. I det hele taget vil det føre ind i en blindgyde at diskutere disse fænomener som generationskonflikt i traditionel forstand og som udtryk for specifikke ungdomsproblemer. Alene det faktum at regeringskommissærerne overalt i Europa har kastet sig over at forklare disse forhold som ungdomsproblemer bør vække til eftertanke.

Bureaukraters, politikeres og mediefolks iscenesættelse af husbesættelser m.v. som uregerlige minoriteters værk kan medføre, at de behov, ønsker og problemer de unge tematiserer, kan udgrænses som minoritetens problemer. Dvs. at de samfundsproblemer og »store spørgsmål«, som tematiseres bliver fjernet fra samfundets overflade. Denne »etnologisering « ${ }^{9}$ af dele af befolkningen kan også funktionalisere de radikale unge til syndebuk, hvad der jo er rimelig efterspørgsel efter for tiden. Derved operationaliseres de radikale unge til at blive objekt for assimilerede befolkningsgruppers projicering af egne angstfølelser, indestængte og fortrængte behov ${ }^{10}$.

I øvrigt er og forbliver det uden mening at tale om ungdom som en homogen størrelse. Alene de mangfoldige subkulturer vidner om forskellighed, ligesom der ikke mindst i disse år er tale om en kraftig differentiering i de unges livsbetingelser. Men dette betyder på den anden side ikke, at der er grund til at undlade at bore dybere $\mathrm{i}$ hvad det egentlig vil sige at være ung og skulle blive voksen i de vestlige samfund i dag ${ }^{11}$.

At diskutere ungdomsprotesten i dens rette sammenhæng vil herefter betyde at tage udgangspunkt ikke så meget i deltagernes alder og udviklingspsykologiske status, men derimod i deres ønsker, angstformer, behov, protest og kritik.

\footnotetext{
6. Hornstein s. 200 og 207.

7. Jvf. f.eks. Härlin.

8. Jvf. Rabehl.

9. Roth. s. 95.

10. Wirth. s. 221.

11. Jvf. afsnit IV \& V.
} 
Der står her klart, at der i ungdomsprotesten tematiseres problemer og behov, som kun for en ringe del kan betragtes som ungdomsspecifikke ${ }^{12}$. Langt snarere er der tale om ønsker og længsler som ethvert fornuftigt menneske burde have. Det, som de radikale unge i deres protest og praksis sætter til diskussion er samfundet, dets livsform og grundlæggende værdier: byernes $\varnothing$ delæggelse af livsbetingelserne, den rigide konsumisme, familiestrukturen, miljøødelæggelsen, arbejdsbegrebet, politikbegrebet osv.

Ungdomsprotesten bliver herefter til samfundsdiskussion og ikke mindst fremtidsforskning.

Men hvordan kan det forklares, at grupper af unge her i 80'erne går så kraftigt på angreb på »normalsamfundet« og dets værdier, og hvordan kan det forklares at de radikale gruppers aktioner og det de står for, ikke længere lader sig uddefinere som en marginal minoritets værk, men tværtimod støder på sympati hos meget brede grupper i ungdommen? ${ }^{13}$

\section{Exkurs: Fra'68 til'80.}

I diskussionen om studenteroprøret, 68'erne og dagens ungdomsprotest verserer en række myter og fordomme. Det følgende skulle helst bidrage med afklaring.

Det er vigtigt at påpege en række forskelligheder mellem de to »oprør«. Først og fremmest finder de sted på forskellige tidspunkter, på forskellige stadier af kapitalismens udvikling og i forskellige samfundsmæssige, politiske og kulturelle situationer. Fra 1968 til 1980'erne har der fundet et skift sted i befolkningens og specielt ungdommens opfattelse af samfundet og dets fremtid. Hvor der i 1968 herskede fremskridtsoptimisme og enighed om at den teknisk-industrielle udvikling ville tjene menneskeheden til bedste, hvis der blot blev grebet korrigerende ind (reformer) under presset fra studenter og arbejderklasse, hersker der idag udbredt fremskridtsangst, troen på at kapitalismen (og socialismen for den sags skyld også) i dens videre udvikling kan tackle de problemer, som den selv avler, er ikke længere tilstede i brede dele af befolkningen og især ungdommen. Hvor der i 1968 var udbredt enighed om betydningen af uddannelse, af de politiske institutioner og rationel diskussion og teori samt tillid til at samfundsudviklingen kunne befries for sine vildskud gennem venstrefløjsindividernes »march gennem institutionerne« er situationen blandt rebellerne idag en helt anden. Optimismen og troen på mulighederne for

12. Ziehe i Bahr.

13. Bacia \& Scherer, Kuntz og Jugendwerk der Deutschen Shell. 
demokratisk, skridtvis forandring gennem de demokratiske institutioner er nu erstattet af billedet af et fuldkomment stivnet politisk system, som hverken formår at levere rimelige bud på fundamentale globale problemer (atomar apokalypse, miljøødelæggelse) eller optage »nye problemer « på dagsordenen. ${ }^{14}$

I denne sammenhæng afskrives reformillusioner og for store dele af de radikale unge er det indtrykket at det er »institutionerne der har marcheret igennem hovedet på 68'erne«.

Ligeledes er der sket en forskydning i »fjendebilledet«. Lidt stiliseret: fra en kamp indenfor samfundet imod kapitalen og om staten, til en kamp udenfor samfundet imod staten og dens tvilling kapitalen, medgden samtidige understregning at hverken kapitalisme eller socialisme byder på rimelige udviklingsmuligheder, de reducerer begge mennesket til arbejdsog konsumkvæg! ${ }^{15}$

Udgangspunktet for protest er så at sige også rykket tættere på individerne. Idag er det ikke længere sådan, at forestillingerne om revolutionen og »den store dag « og kampen for den kan føres sideløbende med at privatlivet og subjektive behov holdes udenfor. Nu er udgangspunktet blevet mere subjektivt og udspringer af de hverdagslige livserfaringer og livsbetingelser. Det er primært dem der skal ændres og helst straks. Hermed er det missionæriske offerberedskab og avantgarde-tænkning blevet afløst af den erkendelse at politik og privatliv er uadskillige.

Det betyder også, at der ikke som før er tale om en primært »abstrakt « teoretisk kritik af samfundet og livsmulighederne, men langt mere en elementær praktisk kritik, hvor det drejer sig om den konkrete realisering af alternative forestillinger ${ }^{16}$. Protestpotentialet er idag også mere bredt i sin sociale rekruttering. Hvor det tidligere var primært studenter og højere mellemlag der førte an, er det i dag socialt meget heterogene grupper der går i aktion og de har resonans i meget brede dele af ungdommen. ${ }^{17}$

Selvom protesten idag slagordsmæssigt kan beskrives som antietatistisk, $\emptyset$ kologisk, mere emotionel, mere anarkistisk og mere pessimistisk ${ }^{18}$ end i 1968 så har bl.a. Hollstein leveret overbevisende argumenter for at dagens ungdomsprotest også står i kraftig gæld til bl.a. 60'ernes hedonistisk

14. Behr. s. 15 .

15. Hollstein i Haller s. 203.

16. Schäfers s. $140 \mathrm{og}$ Behr s. 144.

17. Lessing \& Liebel, Allerbeck, Hollstein i Haller, Dörre \& Schäfer.

18. Richter s. 197. 
orienterede modkulturer i USA, studenteroprøret i Europa og kvindebevægelsen. Ungdomsprotesten i dag videreudvikler det værdigrundlag, de basisdemokratiske eksperimenter og protestformer og alternative livsformer som udvikledes i kimform i 60'erne og 70'erne. Mere rimeligt forekommer det måske at sige, at ungdomsprotesten manifesterer udbredelsen af de ovennævnte former for »afvigende adfærd « og »udenomsparlamentarisk interessevaretagelse « til bredere dele af ungdommen idag.

\section{Kapitalistisk samfundsmoessiggфrelse og unges situation.}

De kapitalistiske samfundsmæssigg ørelsesprocessers fremskredne karakter og deres indtrængen i snart sagt alle samfundsmæssige sfærer fremkalder mangfoldige krisesymptomer i de vestlige samfund, og disse krisesymptomer har allerede længe ikke kunnet defineres som økonomisk krise. Langt snarere er der tale om en enhed af $\varnothing$ konomisk, politisk, social og kulturel krise ${ }^{20}$, eller simpelthen om en krise for den industrielle civilisation.

Der er efterhånden rimeligt belæg for den påstand, at der i og med efterkrigstiden er tale om kvalitative udviklingsspring indenfor de kapitalistiske produktions- og - ikke mindst - reproduktionsforhold. De første er blevet til genstand for omfattende forskning, analyse og teoriopmærksomhed, mens det for de sidste gælder at der efter min opfattelse ikke er ofret tilstrækkelig opmærksomhed på dem.

Dette bliver imidlertid et problem, da det netop er herindenfor at de kvalitative udviklinger gør sig gældende ${ }^{21}$.

Den kvalitative ændring af produktionsprocessen, som Tayloriseringen af arbejdet var udtryk for, og produktionens omlægning fra industrigodeproduktion til produktion af masseforbrugsgoder har haft omfattende følger for hele reproduktionsprocessen. Denne af bl.a. Hirsch betegnede Fordske samfundsmæssigg ørelsesform giver sig udtryk i de kapitalistiske varerelationers »æden sig ind « i førborgerlige relationer, traditioner, normer og værdiorienteringer, som hidtil i væsentlig grad har struktureret re-

19. Jvf. Hollstein 1981 og 1983.

20. Hirsch.

21. Jeg gør mig bestemt ikke til talsmand for, at produktions- og reproduktionsbetingelserne kan analyseres uafhængigt af hinanden. Tværtimod er der tale om, at udviklingen i produktionssfæren afgørende determinerer reproduktionsforholdene, og at netop dette med accelerende styrke slår igennem indenfor de sidste 20-25 år, jvf. Hirsch, Brückner u.a. 
produktionsprocessen. Disse »overleverede« »institutioner « har kapitalen hidtil kunnet udbytte som en »gratis-produktivkraft «, ${ }^{22}$ som har været med til at billiggøre reproduktionsprocessen, at stabilisere socialisations- og integrationsprocesserne. Den tiltagende opløsning af disse førborgerlige reproduktionsformer betyder nu, at de i stigende grad skal produceres samfundsmæssigt (og det vil sige statsligt), ligesom det iøvrigt i tiltagende omfang gælder for produktionens natur-grundlag ${ }^{23}$.

Den Fordske samfundsmæssigg ørelsesforms mest markante kendetegn er en gennemgribende gennemkapitalisering af reproduktionssfæren. Reproduktionsprocesserne organiseres rumligt og tidsmæssigt, de tayloriseres, og det betyder ikke blot segregering af hverdagslivet i adskilte rum, men også at de medmenneskelige relationer bliver sat på vareform - depersonaliseres og sagliggøres.

Som følge af denne gennemkapitalisering forandres ligeledes de sociale relationer, familiens funktionsbetingelser, mellemmenneskelige interaktionsformer, kulturelle traditioner og samfundsmæssige tydningsmønstre. Dette betyder grundlæggende forandrede socialisationsbetingelser, og ikke mindst sætter kapitalistiske samfundsmæssigg ørelsesmekanismer sit præg på menneskenes subjektive, indre strukturer.

Det kapitalistiske samfunds centrale socialisations- og integrationsagenturer - familie, skole og »ideologi« - angribes af samfundsmæssige erosionstendenser. Den accelererende opbrydning af traditionelle netværk og miljøer, udtyndingen af sociale relationer, hverdagslivets opsplitning og gennemfunktionalisering lader den borgerlige kernefamilie undergå en flerdimensionel forandringsproces. Dels aflaster statsliggørelsen af mangfoldige materielle - tidligere »private - reproduktionsydelser familien. Og dels efterlader gennemrationaliseringen og depersonaliseringen af de »offentlige « relationer samt den dominerende livsforms karakter af privatistisk isoleret konsumfællesskab, familien med et stigende pres med hensyn til indfrielsen af emotionelle behov, som ikke finder »udløsning « i det »offentlige « liv.

Herudover intervenerer det udenomliggende samfund på andre niveauer ind i familien. Professionaliseringen af opdragelsen foranlediger en tiltagende subjektiv følelse af pædagogisk dekvalificering og inkompetence hos forældrene. Ligeledes bidrager den samfundsmæssigt frembragte og medieindustrielt forstærkede norm- og værdirelativisme ind i familien, og det samlede resultat bliver en tiltagende social og psykisk rådvild-

22. Jvf. Parin \& Ziehe i Breyvogel.

23. Hirsch. 
hed hos forældrene ${ }^{24}$. Dette kompleks af overfordringer til familien giver sig udslag i omfattende opløsningstendenser - og kort sagt: »familiens krise «.

Familien er med andre ord ikke så gnidningsløst som tidligere i stand til at videregive de for den borgerlige socialkarakter relevante norm- og værdiorienteringer til de opvoksende generationer. Den borgerlige autoritære karakters socialisationsbetingelser undergraves, som følge af de omfattende samfundsmæssiggørelsesprocesser.

Også de statsliggjorte socialisationsapparater angribes af erosionsprocesser og dysfunktion. Den hastige samfundsforandring og nedbrydning af de kulturelle norm- og værdiorienteringer undergraver en af skolens vigtigste sammenholds- og gratisfaktorer: Med opløsningen af de tradierede kulturelle forestillinger, »selvfølgeligheder« autoritetsrelationer og verdens- og livsopfattelser mister skolen »aura « og bliver slet og ret skole - i betydningen anstalt for »tvangssocialisation $\ll{ }^{25}$ hvilket giver sig udslag som en mangfoldighed af tilpasningsproblemer - samlet i begreberne: disciplin- og motivationskrise.

De ændrede socialisationsbetingelser lader sig iagttage som nogle nye norm- og værdiorienteringer, nye adfærdsformer og nye sygdomssymptomer hos de unge.

Der er således tegn på en løsnelse af de psykiske, identitetsmæssige bindinger til lønarbejdet. Dette giver sig udslag i en manglende tilpasning og underkastelse under lønarbejdets rigide funktionalisme, vanskeligheder med at internalisere arbejdsdisciplin og loyalitet, udbredt pjækkeri osv. De unge stiller i stigende grad »radikale « krav til arbejdet, nægter umiddelbart at indordne sig, og selv arbejdsløse tager ikke et hvilket som helst job. ${ }^{26}$

I uddannelsesprocessen og -situationen prioriteres mere umiddelbar selvoplevelse, hvis ikke undervisningen har relation til hverdagen mangler motivationen. Resignation, apati og ligegyldighed breder sig.

Udviklingen er udtryk for en forskydning af identitetsholdepunkterne væk fra lønarbejde og uddannelse og overimod fritidsaktiviteter, kammeratgrupper m.v. Der er kraftige tendenser til opbygning af »vandtætte skodder « imellem det »offentlige« liv i skole og på arbejde og på den anden side fritiden. ${ }^{27}$

Undersøgelser af unges oplevelse af hverdagen udmunder i konklusioner, om at de oplever den som fremmedbestemt, fremmedgjort og gennemregu-

24. Ziehe \& Stubenrauch s. $69 \mathrm{ff}$.

25. Ibid. s. $115 \mathrm{ff}$.

26. Olsen \& Nielsen s. 334.

27. Jvf. Dörre \& Schäfer s. 91ff og Illeris m.fl. s. 144. 
leret, ligesom hverdagens opsplitning virker belastende. Alt i alt er der tegn på nye psykiske lidelser blandt fortrinsvis unge; lidelser der er karakteriseret ved følelsen af indre tomhed, manglende realitetsfornemmelse, manglende initiativ, manglende arbejdsglæde ${ }^{28}$.

Den samfundsmæssige organisering af unge i specielle rum, institutioner og »kulturer « $\mathrm{i}$ en (ganske vist køns- og klassespecifikt) stadig forlænget periode er en mere almen baggrund for udviklingen af »afvigende « adfærd, normer og værdier.

Således foregår identitetsdannelsesprocesser og socialisation i stigende grad i gruppesammenhænge, dels i de socialstatsligt organiserede »rum « (skole, institutioner m.v.) og dels i mere eller mindre selvorganiserede grupper. Disse sidste tilbyder en »ungdomssocialisation i eget regi «, som støtter de unge i deres opposition, emotionelle uligevægt og letter en ungdomsspecifik identitetsdannelse ${ }^{29}$.

Den mangesidede samfundsmæssige og statslige gennemregulering af individerne fra vugge til indtræden i voksenlivet $\mathrm{g} \emptyset \mathrm{r}$ samtidigt ungdommen til en specifik »sfære«, hvor de unge bliver »modtagelig for forskellige former for social indflydelse $\ll^{30}$. Den emotionelle åbenhed og eksperiment-lyst, som præger identitetsperioden gør ungdomsperioden til et socialt frirum, hvor de unge selv kan agere, skabe kulturer stile og symboler ${ }^{31}$.

At medie-, mode- og mainstreamkulturindustrien her har fundet ekspansionsmuligheder kan imidlertid ikke dække over, at der her er et spillerum for afprøvning af (sam)livsformer, biografiovervejelser og fremtidsspekulationer, som udvikles af de unge selv på trods af den udvendige regulering fra samfund og stat.

Statsliggørelsen af socialisationsprocessen, ungdommens institutionalisering i specielle rum og ungdomsperiodens forlængelse konstituerer således dels vanskelighederne med at internalisere en »tilpasning « af forventninger og behov, og på den anden side udviklingsbetingelserne for mere eller mindre »radikale « behov i f.t. uddannelse, arbejde og tilværelsen i det hele taget.

For brede dele af de unge gælder det, at den borgerlige dannelseskanon: flid, pligt, ydelsesberedskab (og først derefter konsum) ikke rigtigt indfan-

28. Olsén \& Nielsen s. 335.

29. Schäfers s. 136.

30. Wirth s. 221.

31. Madsen m.fl. s. 133. 
ger dem, men at de tværtimod kræver et godt, personligt udviklende og meningsfyldt arbejde, solidariske samværsformer i fritiden og i det hele taget et sikkert fremtidsperspektiv osv.

Ungdomsperiodens insulære karakter fremmer hermed udviklingen af forventninger, behov og værdinormer, som på sin side kommer mere og mere i modstrid med den samfundsmæssige realitet, de unge skal konfronteres med i voksenlivet.

Overfor ønsket om det meningsfyldte arbejde står enten arbejdsløsheden eller det monotone, fremmedbestemte arbejde. Overfor behovet for selvbestemte, profitfrie samværsmuligheder i fritiden står eliteidræt og en forhåndsorganiseret og konsumtvingende mainstream-kulturindustri. Og indrammende det hele er der et helt register af globale problemer, der truer det sikre fremtidsperspektiv.

Alt $\mathrm{i}$ alt forøges gabet mellem subjektive behov og den samfundsmæssige udviklings realitet.

\section{V. »Ny subjektivitet «}

Hvordan omgås de unge så med disse perspektiver, hvilke overlevelsesstrategier producerer de? Er der tale om ødelæggelse og destruktion eller frisættes der også protestpotentiale?

Ziehe har forsøgt at fremhæve nogle træk i unges psykiske og kulturelle situation i dag, og hvilke bearbejdningsformer denne situation udvikler ${ }^{32}$.

Under overskrifterne »kulturel frisættelse og kulturel ekspropriation « er hans intention at begribe problemerne og potentialerne $i$ det at være ung i dag. Den kulturelle frisættelse er begrebet for den omfattende frisættelse fra traditionelle kulturelle forestillinger, bånd og handlingsanvisninger, som er resultatet af gennemkapitaliseringen af reproduktionssfæren og samfundsmæssiggørelsen af hverdagslivet. Den kommer til udtryk i forældregenerationens samfundsmæssige dekvalificering, autoritetsrelationernes erosion og arbejdsetikkens forfald. I stedet opstår konturer af en »hedonistisk etik« - prioriteringen af nydelse, selvoplevelse, mening og selvrealisering.

Denne proces er dobbelt: på den ene side er den frigørelse fra en forudbestemt identitet og biografi, og på den anden side åbner den spillerum for kommerciel udnyttelse. Dette spillerum udnyttes dygtigt af ikke mindst medieindustrien med mangfoldigt - i sig selv både integrerende og desin-

32. Jvf. i det følgende Ziehe \& Stubenrauch. 
tegrerende - udbud af behov, »lykkeoplevelser«, »eventyr « m.v. Det bliver $\mathrm{nu}$ - i modsætning til tidligere i historien -muligt at forestille sig allemulige biografier, men samtidigt bliver disse nu kommercielt lanceret som kapitalistiske, forhåndsorganiserede tjenesteydelser.

Denne proces ser Ziehe som en kulturel ekspropriation af mulighederne for at gøre selvstændige erfaringer. Alt hvad man kan forestille sig er allerede besat med samfundsmæssigt tilgængelige erfaringer og tydninger.

Denne »slagmark « mellem kulturel frisættelse og ekspropriation sætter de unge på hidtil usete prøvelser og belastninger rent psykisk. Identitet er ikke mere noget på forhånd givet, og heri ligger der noget frigørelse, men på den anden side bliver de unge med en »åben « biografi, nu selv ansvarlige for deres identitet, psykiske situation og hele liv. Denne eksplosion i samfundsmæssigt producerede biografi- »tilbud « forstærker ydelsespresset og præstationsangsten hos de unge. De skal nu vælge mellem uendelige muligheder og konstant lurer følelsen af at have valgt forkert. Denne udvidelse af det »mulige « sætter sig let som en subjektiv belastning, netop fordi dette mulige ikke er reelt muligt for de fleste, men stadigvæk er du selv ansvarlig.

Dobbeltheden i denne proces viser sig i den samtidige tilstedeværelse af resignation, apati og insisteren på noget andet, emancipation og protest.

I denne proces, - enheden af frisættelse og ekspropriation -, som »indrammer « de unges psykiske og kulturelle situation ser Ziehe nogle dominerende måder psykisk at bearbejde situationen på.

For det første er forøget længsel efter subjektivering i de relationer de unge indgår i i hverdagen. De offentlige relationer - i skole, på arbejde, i.f.t. offentlige myndigheder m.v. - udvikler sig mere og mere målrationalt, og de mellemmenneskelige relationer bliver sat på vareform. Heroverfor stiger de unges behov for at opleve relationer, hvor de har sit selv med, hvor de kan blive beriget følelsesmæssigt og emotionelt. Dette gælder i skolen, på arbejdet, i fritiden og i f.t. politisk aktivitet.

For det andet er der tale om en forøget opmærksomhed omkring selvværdsfølelse. For Ziehe er spørgsmålet om selvværdet blevet den centrale psykiske problematik. Denne voksende sensibilitet overfor selvværdet giver sig til kende som en stigende evne til at registrere, hvad andre vil med een, altså en forøget opmærksomhed om relationers kvalitet.

For det tredie en motivationskrise, eller en legitimationskrise i det psykiske. Denne ytrer sig f.eks. igennem spørgsmålet: »skal jeg finde mig i det?«, et spørgsmål som ikke mindst opløsningen af autoritetsrelationerne har gjort det meget mere nærliggende at stille. Forældregenerationen 
fik at vide, »at sådan er det nu engang! « mens studenteroprørerne kunne spørge: »Er det legitimt?«. Legitimationskrisen viser sig også derved, at totalsamfundsmæssige problemer inddrages i de hverdagslige beslutninger (skal jeg virkelig i skole, på arbejde, det kan jo være ligegyldigt, hvis hele lortet ryger i luften i næste uge). Den borgerlige socialkarakter og internatiseringen af værdimønstre udelukkede sådanne overvejelser (du skal!).

Den fjerde bearbejdningsform ligger i kravet om involverethed,.. Personlige relationer, arbejde, undervisning, fritidsbeskæftigelse bliver vurderet efter hvorvidt man kan finde sig selv og hvorvidt de kan bidrage til et forøget selvværd.

Ziehes metapsykologiske og kulturanalytiske overvejelser kan vel næppe have status af teori, men de er i stand til at indfange nogle træk hos nutidens ungdom ${ }^{33}$, som kan sammenfattes således:

De kapitalistiske samfund befinder sig midt i en fremskreden kulturel og social opløsningsproces, der drives frem af kapitalistiske varerelationers og interaktionsformers »æden sig på« reproduktionssfærens førborgerlige traditioner, livs- og reproduktionsformer, og det i et omfang så det har karakter af en krise for samfundets »subjektbasis ${ }^{34}$. Specielt de unge inddrages i disse omvæltningsprocesser, qva deres placering i en identitetsmæssig og psykisk labil omstillingssituation (ligesom iøvrigt stigende dele af befolkningen (som følge af tvangsmobilisering, arbejdsløshed, ændrede familieforhold osv.)). Situationen er karakteriseret ved dels nye ekspropriations- og integrationsformer, repræsenteret ved medie- og bevidsthedsindustriens »interne « imperialisme og de socialstatslige socialisationsagenturer, og dels ved den samtidige produktion af $»$ overskridende behov og fordringer $«,{ }^{35}$ frisættelse af emancipatoriske muligheder og handlingsforestillinger. ${ }^{36}$.

Herudfra kan der forsigtigt tegnes konturer af en ungdom (og ikke alene ungdom) »udstyret« med en ny subjektivitet - karakteriseret ved på den ene side en ikke-internalisering af de traditionelle norm-og værdiorienterinter,

33. Den voldsomme interesse og diskussion omkring Ziehe (\& Stubenrauchs) vidner trods alt om, at »der er noget om snakken« - lærerværelserne er blevet sat på den anden ende! Jeg er ikke gået ind i diskussionen om Ziehe's tidlige arbejder, hvor diskussionen har været centreret om tidlige brud og frustrationer. Efter min opfattelse har diskussionen til dels været forfejlet. Dette har noget at gøre med at fortvivlede pædagoger og lærere her har kunnet finde noget, at hænge de daglige frustrationer op på. At man på denne måde kan frikende sig selv, bør manden i princippet ikke lastes for!! For nærmere om diskussionen og kritikken se Baethge, Lindner og Nielsen.

34. Brückner u.a.

35. Hirsch.

36. Det er helt givet, at de kulturelle frisætnings- og ekspropriationsprocesser giver anledning til omfattende anomirekationer, eskapisme og selvødelæggelse. 
handlingsanvisninger, autoritære relationer, pligt- og ydelsesdyder, underkastelses- og »tilpasnings«-rationaler og dispositioner for driftsafkald og behovsudskydelse - kort: den borgerlige autoritære socialkarakters grundtræk, og på den anden side en hedonistisk orienteret, selvrealiserings- og selvværdsbetonende værdi- og adfærdsorientering.

\section{Rebellerende unge og det tavse flertal?}

Hvis vi i forlængelse af det foranstående går ud fra, at den kulturelle situation er karakteriseret ved opløsning, værdirelativisme, socialisations- og integrationskrise, bliver ungdomsprotesten at betragte, som et signal om disse tendenser. De rebellerende unge reagerer »seismografisk « på disse udviklinger, »udstiller«, forvrænger og forst $\varnothing r r e r$ gennem deres kulturelle praxis (klædning, happenings, grafiti osv.) deres utilfredshed og kritik af livsbetingelserne.

I fraværet af et »bevidsthedsmæssigt filter«, i form af traditionelle verdens- og livsanskuelser, handlingsanvisninger og erindringer om materiel knaphed, reagerer de unge langt mere sensibelt på de samfundsmæssige forandringer. De unge er i modsætning til de voksne ikke i stand til at stabilisere sig på hverdagens overflade, og således holde mistanken om, at meget af det hverdagen går med slet og ret er vanvittigt, på afstand ${ }^{37}$.

Således bliver spørgsmålet om, »hvad meningen er med det hele? « mere nærliggende at stille sig selv og ikke mindst samfundet. Som sådan må ungdomsprotesten ses som en umiddelbar, ufiltreret reaktion mod den gennemorganiserede meningsløshed. Eller med andre ord en insisteren på mening: meningsfyldte gøremål, meningsfyldt arbejde, meningsfyldte sociale relationer og - mere subjektivt - oplevelse af intensitet, selvbestemte og selvforvaltede sammenhænge. ${ }^{38}$

Ungdomsprotesten bliver således på een gang kritik af den samfundsmæssige modernisering og af de ældre generationers egen »disciplinerings- og ydelseshistorie ${ }^{39}$ samt vigtigst en annoncering af behov, som har dækning hos brede dele af ikke blot unge.

Dette sidste skal her ganske kort sandsynliggøres. Umiddelbart vidner udbredelsen af ungdomsprotestens subkulturelle stiltræk og symbolikker

37. Ziehe i Bjerg \& Elle.

38. Jvf. Ziehe \& Stubenrauch s. $227 \mathrm{ff}$.

39. Ziehe i Bahr. s. 155. 
om en ikke ringe resonans indenfor ungdommen (jvf. f.eks. udbredelsen af graffiti).

Mere gods er der i de efterhånden talrige »ungdomsunders øgelser«. Selvom det ikke er uproblematisk at skulle hente generelle tendenser ud af disse $^{40}$, så kan der dog peges på nogle:

- omfattende ændringer i norm- og værdiorienteringer

- en afstandtagen fra voksengenerationens livsform og livsstil

- at et stort mindretal (10-25\%) betragter sig selv som stående udenfor den herskende kultur

- at flertallet af de unge ser pessimistisk på fremtiden

- at jo mere pessimistisk - jo mere aktiv i kampen for ændringer af de umiddelbare livsbetingelser (forandring er mulig)

- at der selv hos arbejderungdom er tale om en høj grad af sympati med hele spektret af protestbevægelser, lige fra husbesættere, via fredsbevægelse og til øko-bevægelse.

- at det ikke så meget er den sociale baggrund, der determinerer »protestholdninger «, men mere ungdomsperiodens og uddannelsens varighed

- at der er en kraftigt dalende tillid til det politiske systems kanaler, og en ligeså tiltagende tro på andre former for politisk praksis.

Med andre ord: Det bliver stadigt mere umuligt at operere med vandtætte skodder mellem en marginaliseret, radikal minoritet og et tavst velintegreret flertal. Langt snarere er der tale om at den generelle grundstemning hos ungdommen, »at man ikke skal finde sig i hvadsomhelst, at det er nødvendigt at yde modstand og at et bedre, mere humant samfund burde begynde her og nu «, ${ }^{41}$ på hele ungdommens vegne annonceres af de rebellerende unge.

\section{Unge, ungdomsprotest og nye sociale bevagelser.}

De radikale unges kritik af »politik «, det politiske system, partierne og den traditionelle politiske praksis er allerede tidligere berørt ${ }^{42}$

Hos unge $\mathrm{i}$ almindelighed kan der iagttages kraftige tendenser i retning af »politikerlede«, relativ lav partipolitisk organiseringsgrad og lavere valgdeltagelse - i det hele taget indifferens. Men at fortolke dette i retning af en afpolitiseret ungdomsgeneration vil imidlertid være at gå galt $i$ byen. Rimeligvis forholder det sig således, at det politiske system og de traditionelle

40. For kritiske overvejelser se Allerbeck \& Fischer.

41. Dörre \& Schäfer s. 63.

42. Jvf. den i note 4 nævnte litteratur. 
kanaler ikke har ret meget at byde på i forhold til de konflikter, problemer, behov og ønsker unge idag erfarer og oplever som eksistentielle.

I takt med partiernes udvikling i retning af »folkepartier «, uden afgrænset vælgerappeal, social basis og program, og »politikken« udvikler sig til ren og skær administration af »samfundsudviklingens behov og nødvendigheder « forbliver de problemer, som optager de unge ude af den praktiske politiks horisont.

Heroverfor står det så som en kendsgerning, at det ikke blot er de rebellerende unge, der finder det nødvendigt og helt legitimt at fors $\varnothing$ ge behov og interesser gennemsat ved udenomsparlamentarisk aktivitet, men at dét i stigende grad bliver ungdommens foretrukne politik-form.

Og dette kan ikke blot forklares udfra (manglende) egenskaber i de traditionelle politiske kanaler: Deltagelse i græsrodsbevægelser, alternative kulturelle manifestationer og sociale bevægelser tilbyder på mange måder samværsformer, aktionsformer og sammenhænge som modsvarer mange unges behov.

Således er alternativbevægelse, forsøgene med anderledes livsformer og alternativkultur organiseret på en sådan måde, at de så at sige tilbyder en forlængelse af ungdomsspecifikke samværsformer -gruppeorganiseret, solidarisk, selvbestemt osv.

Endvidere tilbyder deltagelse i alternativbevægelse og nye sociale bevægelser også løsningsmuligheder på de problemer unge står i midt i identitetsdannelsesprocessen og personlighedsudviklingen. Det stadigt stigende gab mellem på den ene side de systematisk producerede overskridende forventninger og behov - som unge »rammes « hårdest af -, og på den anden side de indsnævrede muligheder for at realisere disse behov »indenfor « den dominerende livsform, kan i det mindste her finde een mulig bearbejdningsform. Behovet for meningsfuld beskæftigelse kan kombineres med solidariske sociale relationer og modstands- og forandringstrang, og det med nogle konsekvenser som både rækker ud over ungdomsperioden og ud i samfundet.

Dette giver sig ikke alene udtryk i, at unge er det væsentligste rekrutteringsområde for alternativbevægelse og nye sociale bevægelser, men også i at brede grupper af unge nærer udbredt sympati for disse bevægelsers målsætning og aktionsformer.

Herefter kan der sammenfattes således: De omfattende samfundsmæssige forandringer - ikke mindst indenfor reproduktionssfæren - gør store dele af ungdommen »modtagelig « for kritik af den industrielle civilisation, for de målsætninger, modstandsformer og livsformer, der ligger indenfor ungdomsprotestens, alternativbevægelsens og de nye sociale bevægelsers felt. 
Ungdommens samfundsmæssige integration er herefter sat som et væsentligt samfundsmæssigt problem.

\section{Ungdommens samfundsmassige integration - problemer og perspektiver.}

Vi kan således fortolke udviklingen af de kapitalistiske produktions- og ikke mindst reproduktionsforhold som et kraftigt tab af traditionelt integrationspotentiale, der viser sig som

- omfattende tendenser til værdiforandring hos først og fremmest de yngre generationer. Det borgerlige samfunds værdikodex »fanger« ikke længere de unge og anfægtes af et nyt, hedonistisk og forandringsorienteret normog værdimønster, hvor først og fremmest spørgsmålet om selvbestemmelse, mening og subjektivering er centrale.

- en udbredt mistillid til den fortsatte teknisk-industrielle udvikling, legitimiteten af den statsadministrative handlen og det politiske systems deltagelsesmuligheder.

Denne udbredte desintegration er naturligvis ikke kun positiv -mht. emancipationsforhåbninger. I kølvandet på desintegrationstendenserne følger mangeartede negative konsekvenser i form af anomireaktioner: selvødelæggelse, (druk, dope, junk og selvmord), eskapisme (konsumfetichisme, ny religiøse bevægelser) individuel og kollektiv kriminalitet osv. Men samtidigt frisættes der altså også modstandsvilje og forandringspotentiale.

Det samfundsmæssigt producerede tab af integrationspotentiale modificeres imidlertid ved en samtidig udvikling og produktion af nye integrationsformer.

Den bevidsthedsindustrielt organiserede ekspropriation af unges selvproducerede sub- og modkulturelle bearbejdnings- og protestformer, og deres omformning til affirmativ konsumkonkurrence i mainstreamkulturen er i denne sammenhæng en ikke uvæsentlig integrationsform.

Det vigtigste - og ikke mindst politisk-strategisk mest centrale er imidlertid den stadigt mere direkte socialstatslige og politistatslige flankering af ikke alene unges, men hele befolkningens livs- og udfoldelsesmuligheder. Udbygningen af et stadigt mere perfektioneret kontrol-, disciplinerings- og overvågningssystem, som er et strukturelt kendetegn ved de højtudviklede kapitalistiske samfund ${ }^{43}$, er ikke mindst i forbindelse med ungdomsprotesten og de nye sociale bevægelser blevet synligt og nærværende.

43. Hirsch. 
Denne udbygning af kontrolapparatet - som mere og mere får »præventiv« karakter, dvs. er i spil før eventuel illegitim adfærd og politisk aktion rent faktisk virkeliggøres - konstituerer konturerne af et nyt legitimationssystem.

I fraværet af en minimalkonsensus i befolkningen omkring samfundssystemets grundværdier bliver det nu de samfundsmæssige, dvs. statslige institutioners funktionalitet og stabilitet, der skal garantere at samfundet ikke falder fra hinanden. Med andre ord: garantien for samfundssystemets bevarelse og videreudvikling på kapitalistiske produktions- og reproduktionsforholds præmisser bliver et spørgsmål om de omsiggribende social- og sikkerhedsapparaters evne til dels præventiv »normalisering « af befolkningen og dels kriminalisering og repressiv udgrænsning af minoriteter. I kølvandet herpå er der udbredte afdemokratiseringstendenser og undertrykkelse af protest- og modstandsmuligheder. Reproduktionen af de kapitalistiske produktions- og reproduktions forhold og gennemsættelsen af værdiloven fordrer i stigende grad (sikkerheds-)statslige reguleringer helt ind i reproduktionssfærens, hverdagslivets og individernes inderste porer. Herved tangeres grundmodsætningen i det kapitalistiske samfund lønarbejde/kapital - af en ny modsætning: stat/folk.

Hermed er der sat en voldsom udfordring for samfundsforandrende kræfter. Den traditionelle venstrefløj må »åbne« op overfor de nye sociale bevægelser, ændre politikopfattelse og politikbegreb. De nye sociale massebevægelser må finde et overgribende forandringsperspektiv - under bevarelse af mangfoldigheden. Forandringens nødvendighed har aldrig tidligere i civilisationens historie været større - såvel »menneskeligt« som økologisk.

44. Brand og Hirsch. 


\section{Litteraturliste.}

Allerbeck, Klaus R.: Ein generationenkonflikt? Der Ertrag der Jugendstudien: Versuch einer Bilanz, i: Jugend, Jugendprobleme, Jugendprotest.

Aust, Stefan \& Sabine Rosenbladt (hrsg): Hausbesetzer. Wofür sie kämpfen, wie sie leben und wie sie leben wollen. Hoffmann \& Campe, Hamburg, 1981.

Bacia, Jürgen \& Klaus-Jürgen Scherer: Passt bloss auf!! Was will die neue Jugendbewegung. Olle \& Woller (Edition Vielfalt), Berlin, 1981.

Baethge, Martin u.a.: Jugend ung Krise - Krise aktueller Jugendforschung. Forschungsberichte des Sociologischen Forschungsinstitut, Göttingen (SOFI). Campus, Frankfurt, New York, 1983.

Bahr, Hans-Eckehard (hrsg): Wissen wofür man lebt. Kindler Verlag München, 1982.

Bay, Joi: Storbyens magikere - om »Birminghamskolens« subkulturteori, i Bidrag nr. 16, 1983.

Behr, Wolfgang: Jugendkrise und Jugendprotest. Kohlhammer, Stuttgart, 1982.

Bjerg, Jens \& Birgitte Elle (red): Ungdom, socialisation og narcissisme. Unge Pædagoger, Kbh. 1982. Bjørnshauge, Lars: artikelserie i Blød By nr. 23, 25, 26 og 27: Velkommen til Paranoia City. Kraakstad Amsterdam. Lieber instandbestezen als kaputtbesitzen. Ungdomsbevægelser? 1983-84.

Bopp, Jörg: Angstens magt, i C. Jensen.

Brand, Karl-Werner: Neue soziale Bewegungen: Entstehung, Funktion und Perspektive neuer Protestpotentiale. Ein Zwischenbilanz. Westdeutsher Verlag, Opladen 1982.

Brand, Karl-Werner u.a.: Aufbruch in eine andere Gesellschaft. Neue soziale Bewegungen in der BRD. Campus, Frankfurt 1983.

Brandes, Wolkhard \& Bernhard Schön (hrsg): Wer sind die Instandbesetzer? Päd. extra Verlag. Bernsheim, 1981.

Breyvogel, Wilfried (hrsg): Autonomie und Widerstand. Zur Geschichte des Jugendprotestes. Rigodon Verlag. Essen, 1983.

Brückner, Peter u.a.: Den inre naturens industrialisering. Kapitalism och borgerligt samhälle. i Tekla nr. 12/13, 1982.

Deutsches Jugendinstitut (hrsg): Die neue Jugenddebatte. Was gespielt wird und um was es geht. Schauplätze und Hintergründe. Juventa Verlag, München, 1982.

Dörre, Klaus \& Paul Schäfer: In den Strassen steigt das Fieber. Jugend in der BRD. Pahl-Rugenstein, Köln, 1982.

Eckert, Roland: Das Messen der Aussenwelt an der inneren Sinnvorstellungen. Bewegung der Jugend und organisierte Politik, i Jugend, Jugendprobleme, Jugendprotest.

Fischer, Arthur: Jugend heute: Ergebnisse einer Untersuchung, i Jugend, Jugendprobleme, Jugendprotest.

Gekeler, Wolfram u.a.: Wer nur auf Pflastersteine reagiert, darf sich nicht wundern, wenn - auch Pflastersteine fliegen! Das politische Bewusstsein der neuen Jugendbewegung als Infragestellung der alten »Neuen Linken«, i Brandes \& Schön.

Haller, Michael: Aussteigen oder Rebellieren. Jugendliche gegen Staat und Gesellschaft. Rowohlt, Hamburg, 1981.

Haller, Michael \& Vera Isler: Die Kunst der Verweigerung. Wandmalereien in den Autonomen Jugendzentren der Schweiz. Verlag Pro Juventute, Zurich, 1982.

Hebdige, Dick: Subculture - the meaning of style. London 1979.

Hirsch, Joachim: Der Sicherheitsstaat. Das Modell Deutschland. Seine Krise und die neuen sozialen Bewegungen. EVA, Frankfurt 1980.

Hirsch Joachim \& Roland Roth: Statens krise og de nye sociale bevægelser, i Grus nr. 3, 1981.

Hollstein, Walter: Autonome Lebensformen. Über die transbürgerliche Perspektiven der Jugendbewegung, i Haller, 1981.

Hollstein, Walter: Die Gegengesellschaft. Rowohlt, Hamburg, 1981.

Hollstein, Walter: Die gespaltene Generation. Jugenliche zwischen Aufbruch und Anpassung. Dietz, Bonn, 1983. 
Hornstein, Walter: Unsere Jugend. Über Liebe, Arbeit, Politik. Weinheim \& Beltz. Basel, 1982.

Härlin, Benny: Fra hus til hus, i C. Jensen.

Jugend, Jugendprobleme, Jugendprotest. Kohlhammer Taschenbücher. Stuttgart, 1982.

Jugendwerk der Deutschen Shell: Jugend '81. Lebensentwürfe, Alltagskulturen, Zukunftsbilder. Bd. 1-3. Leske \& Budrich, 1982 Näherungsversuche Jugend 81. Leske \& Budrich. 1983.

Illeris, Knud, Elo Nielsen \& Birgitte Simonsen: Ungdomspsykologi. Samfundssituation, handlemønstre, bevidsthedsformer. Unge Pædagoger. Kbh. 1982.

Jensen, Carsten (red): BZ Europa. Tiderne Skifter, Kbh. 1982.

Kuntz, Karl-Michael: Spontis, Schlaffis \& Chaoten, i Aust \& Rosenbladt.

Lessing, Helmut \& Manfred Liebel: Jeder braucht Jeden. Das Protestpotential geht quer durch alle Schichten, i Brandes \& Schön.

Lindner, Rolf: Kulturanalytiske bemærkninger til den nyere ungdomskrise, i Bjerg \& Elle.

Madsen, Turi Rye, Claus Mellergaard \& Leif Thomsen: Ungdom 80. Ungdom som social bevægelse. Forlaget Politiske Studier, Kbh. 1982.

Müller-Münch, Ingrid u.a.: Bestezung - weil das Wünschen nicht geholfen hat. Rowohlt, Hamburg, 1981.

Mørch, Svend: Ungdom og modkultur - om Birminghamskolens bidrag til en ungdomsforskning, i Udkast nr. 2, 1981.

Nielsen, Henrik Kåre: Narcissisme, autonomi og emancipation, i Psyke \& Logos, nr. 1, 1983.

Olsén, Peter \& Birger Steen Nielsen: Unge og arbejdsløshed, i Udkast, nr. 3-4, 1981.

Oltmanns, Reimar: Du hast keine Chance, aber nutze sie. Eine Jugend steigt aus. Rowohlt, Hamburg, 1980.

Parin, Paul \& Thomas Ziehe: Kulturkrise und Revolte, Ethnologische und Kulturtheoretische Beiträge zur Jugendrevolte, i Breyvogel.

Rabehl, Bernd: Im Kampf gegen die Polizei werden sie die Gestalt der Polizei annehmen, i

Bacia \& Scherer.

Richter, Horst Eberhard: Den nye sensibilitet, i C. Jensen

Roth, Roland: Die Indianer sind fern, i Widersprüche nr. 4/5, 1982.

Schäfers, Bernhard: Die Jugendliche ung die Alternativen, i Jugend, Jugendprobleme, Jugendprotest.

Wirth, Hans-Jürgen: Verweigerungswünsche. Über die Jugend als Projektionsleinwand unerfüllter Bedürfnisse, i Haller, 1981.

Ziehe, Thomas: Jugendliche sind nicht mehr »jugendlich«, i Bahr.

Ziehe, Thomas: Om narcissismens sårbarhed. Kulturelle frisætningsprocessers psykiske nedslag, i Bjerg \& Elle.

Ziehe, Thomas \& Herbert Stubenrauch: Ny ungdom og usædvanlige læreprocesser. Politisk Revy, Kbh. 1983. 